\title{
Konsep Allah Dalam Teologi Proses
}

\author{
Ceria $^{1 *}$, Rima Kurnia ${ }^{2}$, Dian Lestari Hondro ${ }^{3}$, Eko Prasetyo ${ }^{4}$, Mangiring Tua \\ Togatorop ${ }^{5}$ \\ 1,2, ${ }^{3}$ Mahasiswa Pasca Sarjana Prodi Teologi, STT Real Batam \\ ${ }^{4,5}$ Prodi Teologi, STT Real Batam \\ ceria2988@gmail.com
}

\section{Abstract}

The writing of this scientific paper is devoted to discussing God as formulated in process theology, which was initiated by Alfred Whitehead. In this section the author presents the concept of God in process theology and how to respond to the concept in a Biblical manner. The research method, the author uses a qualitative descriptive analysis research method approach, with a literature approach and belongs to library research. The concept of God according to process theology is God who is in process, impersonal and does not have absolute sovereignty. But the view of God in process theology is a collection of personal experiences and is made into a concept in human thought. The response shows a comparison of the process theology mindset about God that is distorted and leads one to understand the true concept of God according to God's statement through the Bible.

Keywords: Image, God, Response, Process Theology

\begin{abstract}
Abstrak
Penulisan karya ilmiah ini dikhususkan untuk membahas mengenai Allah yang dirumuskan dalam teologi proses, yang dicetuskan oleh Alfred Whitehead. Dalam bagian bagian ini penulis menyajikan konsep Allah dalam teologi proses dan bagaimana tanggapan terhadap konsep tersebut secara Alkitabiah Metode penelitian, penulis menggunakan pendekatan metode penelitian kualitatif analisis deskriptif, dengan pendekatan literatur dan tergolong dalam penelitian perpustakaan. Konsep Allah menurut teologi proses adalah Allah yang berproses, tidak berpribadi dan tidak memiliki kedaulatan absolut. Namun pandangan tentang Allah dalam teologi proses adalah suatu kumpulan pengalaman pribadi dan dijadikan sebagai suatu konsep dalam pemikiran manusia. Tanggapan tersebut menunjukan perbandingan dari pola pikir teologi proses mengenai Allah yang menyimpang dan mengarahkan seseorang dalam memahami konsep Allah yang benar sesuai dengan pernyataan Allah m
\end{abstract}

Kata kunci: Gambar, Tuhan, Respon, Teologi Proses 


\section{PENDAHULUAN}

Pusat Penulisan karya ilmiah ini di khususkan untuk membahas mengenai Allah yang dirumuskan dalam teologi proses, yang dicetuskan oleh Alfred Whitehead. Artikel ini dikhususkan untuk membahas mengenai Allah yang dirumuskan dalam teologi proses, yang dicetuskan oleh Alfred Whitehead. Dimana Alfred North Witehead adalah seorang ilmuan, ia juga aktif dalam bidang kritik ilmu pengetahuan.

Menurut Whitehead, Allah adalah pencipta alam semesta. Penciptaan Allah tersebut dikatakan sebagai evolusi yang terus-menerus, suatu hidup bersama ketertiban dan kebebasan dimana manusia ikut berperan dalam menentukan masa depan. Sehingga pada pusat pengajarannya tidak ada Allah yang berdaulat, yang mengatur, dan membentuk sejarah dan manusia. ${ }^{1}$ Ia tidak bebas dari pengaruh ciptaan-Nya. Ia memberikan kebebasan yang sejati walaupun terbatas kepada alam semesta supaya kita dapat menjadi sebab dan Ia menjadi akibat. Jadi intinya Whitehead telah menolak ajaran tradisional tentang Allah. ${ }^{2}$

Teologi ini diawali dari ilmu filsafat yang berkembang dalam dunia teologi, mengangkat kosnsep tentang Allah yang menjadi bagian penting dalam teologi porses dengan tujuan menyatukan kesalahpahaman pandangan tentang Allah dan menghubungkan suatu konsep dengan konsep lainnya, antara konsep baru dan konsep yang sudah ada dalam pemikiran kebanyakan orang saat itu, sehingga terbentuk konsep yang salah dan bertentangan dengan sehingga terbentuk konsep yang salah dan bertentangan dengan pengertian para ahli Fisika. Teologi ini juga memiliki memiliki kesimpulan teologis dan pengenalan yang bertolak belakang dengan konsep Allah secara Alkitabiah. Dalam bagian bagian ini penulis menyajikan konsep Allah dalam teologi proses dan bagaimana tanggapan terhadap konsep tersebut secara Alkitabiah. Hal ini didasari karena dalam perkembangan konsep Allah ini telah dikaitkan dengan teologi Kristen, akan tetap isi dari konsep Allah tersebut jauh berbeda dengan konsep Allah menurut teologi Kristen. Tujuan yang ingin dicapai melalui tulisan ini adalah adanya sebuah langkah apologetika Kristen, sehingga mampu memberikan perbedaan konsep Allah dalam teologi proses dan pemahaman yang benar tentang konsep Allah menurut Alkitab

\section{METODE}

Metode penelitian, penulis menggunakan pendekatan metode penelitian

\footnotetext{
${ }^{1}$ Harvie M Conn, Teologi Kontemporer (Malang: Literatur SAAT, 2012) hal. 131.

${ }^{2}$ Moody Goni Daniel, "Teologi Proses," Jurnal Teologi Biblika dan Praktika 53, no. 4 (2018). hal 82.
} 
kualitatif analisis deskriptif, dengan pendekatan literatur dan tergolong dalam penelitian perpustakaan, dan penelitian ini dilakukan dengan cara mempelajari setiap data berupa dokumen atau penelitian terdahulu dari berbagai buku yang berkaitan konsep Allah berdasarkan perspektif teologi proses dan tanggapan terhadap konsep tersebut dengan secara spesifik, beberapa buku yang menjelaskan tentang teologi proses menjadi sumber utama dari penelitian ilmiah ini.Demikian juga Sugiono mengungkapkan bahwa penelitian deskriptif kualitatif adalah penelitian yang berusaha untuk menuturkan pemecahan masalah yang ada berdasar data-data mengikuti teknik pengolahan dan analisis data. ${ }^{3}$

\section{HASIL DAN PEMBAHASAN}

\section{Konsep Allah dalam Teologi Proses}

Hal penting yang perlu diketahui tentang konsep Allah dalam Teologi Proses adalah diawali dengan dasar dari lahirnya teologi proses yang merupakan hasil dari filsafat proses yaitu sebuah usaha untuk memdamaikan intuisi yang merupakan daya atau kemampuan mengetahui dan memahami sesuatu yang beragam dari hasil pengalaman manusia seperti dalam bidang agama, ilmiah dan keindahan. Menurut Hermawan, Whiehead membahasakan adanya keberadaan yang sesungguhnya terjadi saat itu, dimana dalam proses metafisika keberadaan tersebut bukan sepenuhnya menjadi penentu dari sebuah aktifitas. $^{4}$

Harvie dalam buku Teologi Kontemporer mengatakan bahwa Para teolog proses menolak konsep Alkitabiah mengenai Allah sebagai Oknum yang melampaui atas alam semesta, akan tetapi segala sesuatu terjadi dalam Allah. ${ }^{5}$ Namun hal ini tidak menerima banyak perhatian orang-orang dalam teologi proses karena ilmu pengetahuan dan kemahaadaannya dan kemahakuasaannya belum mencapai pengaruh yang menentukan seperti dalam kebudayaan Barat dan Jepang. Tekanan yang ada tidak cukup menciptakan suatu teologia sintesa yang baru, yang sejalan dengan paham teologi proses.

Hartshorne dalam Hermawan mengatakan jika interaksi antara partikel atom dan sub atom merupakan proses yang menghasilkan keberAdaan baru. ${ }^{6}$ Jadi proses tersebut terjadi karena karena adanya hubungan saling memberi satu dengan yang lain dan menghasilkan yang lain. Proses ini

16

${ }^{3}$ Sugiono, Memahami Penelitian Kualitatif (Bandung: CV Alfabeta, 2016). Hal.

${ }^{4}$ Hermawan, "Respons Terhadap Konsepsi Allah," Jurnal Teologi Kristen 1, no. 1 (2019).hal. 51

${ }^{5}$ Conn, Teologi Kontemporer. hal 133.

${ }^{6}$ Hermawan, "Respons Terhadap Konsepsi Allah". hal 51. 
akan terus berlanjut dan tidak berhenti sehingga dinamakan sebagai unsur yang kekal dalam filsafat proses.

\section{Konsep Allah yang Berproses}

Gambaran Allah dalam pemikiran para teolog proses adalah Allah yang memiliki natur yang akan selalu mengalami perubahan atau proses, sehingga dapat memiliki hubungan dengan dunia. Karena alam dan manusia mengalami perubahan maka Allah pun juga mengalami perubahan memiliki natur yang selalu dalam perubahan atau proses sehingga dapat bersentuhan dan berelasi dengan dunia. Karena alam dan manusia mengalami perubahan maka Allah pun mengalami perubahan yang secara secara terus menerus. Whitehead dalam Hermawan menjelaskan tentang dua kutub "dipolar" yaitu kutub fisik dan mental, disebut juga primordial nature dan consequent nature. Dimana kutub fisik merupakan kutub yang mengalami perubahan, dan kutub mental tidak mengalami perubahan akan tetapi keduanya saling memeliki keterkaiatan satu dengan yang lain.

Jika gambaran Allah dalam teologi proses bukanlah Allah yang tidak berubah, akan tetapi Allah yang akan mengalami perubahan terus menerus, Jadi memang Allah dari teologi proses adalah Allah bukanlah Allah yang tidak berubah atau mengalami perubahan terus menerus. Suhermanto dalam tulisannya menyatakan jika apa yang terjadi di masa lalu sebagai kutub "fisik" sedangkan yang akan terjadi di masa depan, belum terealisasi tetapi sksis dalam batasan-batasan kemungkinan dan masih dipikirkan adalah kutub "mental". Allah memiliki kedua natur tersebut didalam diri-Nya. Bagaian tersebut terbagi atas primodial yang meliputi hal keteraturan, keharmonisan dari objek yang kekal seperti sebuah bayangan dan aturan dari objek abadi kedalam sebuah ide yang sulit untuk dibayangkan dan cenderung rumit.

Dorothy dalam bukunya menyatakan jika dalam teologi proses Allah tidak terpisah dari proses-proses dunia, sebagai Allah yang memiliki wujud, Allah memiliki masa lalu dan masa depan potensial. Dimana dalam masa depan Allah mempertimbangkan segala scenario yang mungkin akan terjadi dan menghadirkannya dihadapan manusia dalam wujud yang memikat terhadap pontensi mereka. Teologi proses ini menganggap jika manusia merupakan tekan sekerja Allah dan bukan sebagai objek ilahi uang dibatasi hanya untuk melakukan kehendak Allah.

Jadi Allah berkontribusi ke dalam dunia namun Allah juga diciptakan oleh dunia. Ini lah yang dimaksud dengan Allah proses yang memiliki dua natur bipolar. dimana salah satu natur tersebut berinteraksi langsung dengan dunia dan dunia memberikan pengaruh besar bagi Allah, natur tersebut juga 
mempengaruhi dunia walapun hanya bersifat pasif dan tidak menentukan apapun.

\section{Konsep Allah yang Tidak Berpribadi}

Teologi proses memiliki kecendrungan untuk menghilangkan Allah sebagai Oknum yang berpribadi. Allah di kurangi menjadi suatu aspek utama dari keseluruhan segala sesuatu. Sekalipun Allah tetap diakui sesbagai sesuatu yang sungguh-sungguh ada. Hartshorne dalam Harvie mendefinisikan Allah sebagai oknum yang hidup namun ia meragukan apakah ada yang sungguh memberi arti Oknum yang lebih dari arti yang diberikan Whitehead, yaitu deretan pengalaman yang mempunyai sifat tertentu dan yang di atur secara pribadi. ${ }^{7}$ Ini menunjukan pada perbedaan Allah dalam Alkitab yang berpribadi menyatakan diri-Nya, berbicara dan bertindak untuk diri-Nya sendiri, memaparkan tujuan-Nya secara nyata. Namun Allah dalam teologi proses adalah suatu kumpulan pengalaman yang diatus secara pribadi sebagai seuatu konsep dalam pemikiran manusia.

Whitehead dalam Hermawan, menyatakan bahwa Allah yang di dalam teologi proses adalah yang banyak itu menjadi satu dan mengalami peningkatan. Artinya Allah proses tidak bisa ditunjukan oleh satu yang "Ada". ${ }^{8}$ Karena itu Allah merupakan perwujudan pertama "kreativitas" yang keberadaannya tidak dapat dipisahkan dari eksistensi lain. Dalam perkembanganya istilah yang menggambarkan defenisi Allah tersebut dibahasakan kedalam bahasa agama, sebab tidak ada keterkaitan yang bisa menggambarkan pengertian tentang Tuhan Allah dengan memakai bahasa singularitas. Karena jika tidak demikian, konsep Allah dalam teologi proses akan sulit untuk dijelaskan dalam kerangka yang mudah dimengerti. Teologi proses dalam pertimbangan metafisika hanya memandang Allah sebagai abstraksi. Karena Allah hanya dibatasi sebagai potensi, mengasihi namun tidak mampu bertindak sesuai keinginannya sendiri untuk mengasihi. Allah hanya bagaikan bayang-bayang dan bukan tokoh sentral di dalam sejarah manusia.

\section{Konsep Allah Yang Tidak Memiliki Kedaulatan Absolut}

Pandangan Teologi proses mengenai Allah sering di sebut juga dengan panenteisme atau teisme neonklasik, dimana Allah di pengaruhi dunia dan mempengaruhi dunia. Semua terjadi didalam dia, artinya dunia adalah

\footnotetext{
${ }^{7}$ Conn, Teologi Kontemporer. hal 132.

${ }^{8}$ Hermawan, "Respons Terhadap Konsepsi Allah". hal. 54 "
} 
tubuh Allah, dan hubungannya sama seperti hubungan otak dengan tubuh. ${ }^{9}$ Teologi proses dalam pemikiran ilmu filsafat merumuskan tentang Allah yang berasal dari entitasentitas dalam sebuah kejadian yang saling berinteraksi satu dengan yang lain dan menghasilkan sesuatu yang lain. Allah memiliki daya penentu namun tidak sepenuhnya bisa mementukan segalanya sendiri. Jadi Allah dalam teologi proses bukan Allah yang memiliki kekuatan mutlak dalam mentukan arah dan kejadian menurut keinginan-Nya. Cobb dalam Anodya menyatakan Allah sebagai Moralis Kosmis, yang menggambarkan Allah sebagai hakim langit dengan minat utama pada perkembangan tingkah laku moral dam membatasi manusia sesuai dengan tidakan moral, Cobb pernah membeberkan mengenai pertanyaan yang di ajukan oleh Romano Guardini seorang teolog katolik, didalam dunia kenapa masih ada kejahatan bahkan penderitaan, katanya Allah baik namun kenapa masih ada persoalan persoalan yang mesti terjadi,knp masih ada penderitaan bagi mereka yang tidak bersalah, bahkan pertanyaan ini sering muncul di akhir akhir ini,kenyataan Tuhan itu maha pencipta dan mahatahu lalu kenapa masih ada kejahatan. ${ }^{10}$ Paham ini secara tidak langsung menjelaskan tentang Allah yang tidak memiliki kekuatan mutlak dalam menentukan arah maupun kejadian- kejadian menurut keinginan-Nya.

Kekuatan Allah teologi proses adalah ikut merasakan dan menanggung rasa sakit akibat kejahatan dunia. Bukan meniadakan kejahatan. Pandangan lain tentang teologi proses menurut Jessica adalah teologi proses memandang Allah sebagai Allah yang memiliki kuasa, tetapi kuasa yang dimiliki-Nya tidak seperti yang di jabarkan para teolog tradisional. Kuasa yang dimiliki Allah merupakan kuasa untuk mempengaruhi dan memersuasi ciptaan-Nya. Ia bukan Allah yang berkuasa dalam menentukan segala sesuatu, dan Allah yang memiliki kuasa absolut menurut teologi proses adalah Allah berhala. $^{11}$

Pandangan kontemporer ini tentu saja sangat berbahaya bagi kekristenan karena pandangan kontemporer ini tentu saja sangat berbahaya bagi kekristenan kerena pandangan ini menjadikan Allah hanya sebagai Allah yang lemah dan tidak bedaya. Pemikiran teologi proses tentang Allah tidak

\footnotetext{
${ }^{9}$ Ja'far Suhermanto, “Aku Dalam Tuhan: Implikasi Teologi Proses Pada Era Kontemporer," Ulumuna 16, no. 2 (2012). hal. 347.

${ }^{10}$ Anodya Ariawan Soesilo, "Teologi Proses Mengenai Allah Dan Problem Kejahatan: Suatu Tinjauan Atas Kasus Al-Nakba," Gema Teologika 2, no. 2 (2017): hal. 151.

${ }^{11}$ Jessica Novia Layantara, "Kritik Terhadap Teologi Proses Dan Pembelaan Terhadap Pandangan 'Greater Good' Dalam Menanggapi Masalah Kejahatan," Veritas : Jurnal Teologi dan Pelayanan 16, no. 2 (2017). hal. 158.
} 
sesuai dengan apa yang tertulis dalam Alkitab.

\section{Tanggapan Terhadap Konsep Allah Proses}

Tanggapan yang disajikan bukan hanya berdasarkan prespektif teologi Kristen dan juga berdasarkan kerangka berpikir menurut konsep Allah dalam teologi proses. Pertama, dimana Whitehead mengatakan bahwa ia memperkenalkan Allah melalui proses metafisika, dan Tuhanlah yang menentukan batasan antara masa lalu, masa kini, dan masa depan. Dengan kata lain ia mengakui konsep Allah plural, dan percaya adanya konsep penentu dalam teologi proses. Akan tetapi pemikiran tersebut hanya berdasarkan pengalaman dan pemikiran yang logis dan bukan berdasarkan pernyataan Ilahi yang ajaib dari kebenaran tentang Allah menurut Alkitab, dan pemikiran mereka melawan wahyu khusus yang dinilai sebagai kepasrahan. ${ }^{12}$

Tentang paham konsep Allah yang tidak memiliki kedaulatan Absolut, teologi proses sangat yakni pada saat menolak teodisi tradisional kemahakuasaan Allah. Seorang teolog bernama David Ray Griffin menyatakan teodisi tradisional secara tidak kebetulan menepatkan Tuhan Allah sebagai penyebab dari kejahatan. Griffin juga telah mengomentari pembelaan keinginan hasrat atau kehendak bebas. Ia tidak menyetujui solusi maupun saran yang membawa pembelaan atau keinginan hasrat atau kehendak bebas yakni kemenangan di dalam kehidupan dimasa mendatang. ${ }^{13}$ Menurut Griffin solusi itu hanya sekedar penanggulangan iman akan tetapi tidak memberi jawab mengenai persoalan logisnya. Sebaliknya teologi proses itu memperhatikan Allah sebagai Tuhan yang mempunyai kuasa, akan tetapi kuasa yang ada tidak seperti yang dipaparkan oleh teolog-teolog trasional. Kuasa yang Tuhan Allah miliki adalah kuasa untuk dapat mempengaruhi ciptaan-Nya. Allah bukanlah Tuhan yang ingin menguasai kekuasaan dengan menempatkan segala sesuatu. Adapun kritik dalam sebuah pandangan teologi proses dapat dibagi menjadai dua yakni yang pertama adalah jelas jika pandangan atau tanggapan ini tidaklah alkitabiah. Bukti alkitabiahnya tidak ada yang mengatakan jika Tuhan Allah hanya mempunyai kuasa untuk menghasut umat-Nya. Allah yang digambarkan dalam alkitab adalah Tuhan Allah yang memiliki daulat yang Mahakuasa dan dapat serta berhak menetukan segala sesuatu. Kemudian yang kedua adalah bahwa teologi proses tidak mempunyai akhir yang nyata. Ini menjelaskan bahwa Allah seolah-olah tidak berkuasa atas akhir dunia ini. Bahkan Griffin juga mempertimbangkan

\footnotetext{
${ }^{12}$ Conn, Teologi Kontemporer.

${ }^{13}$ Soesilo, "Teologi Proses Mengenai Allah Dan Problem Kejahatan: Suatu
} Tinjauan Atas Kasus Al-Nakba." hal. 152" 
bahwa akhir dunia ini tidak ditetapkan oleh Tuhan Allah meskipun masih dapat berharap jika kebaikan akan menang atas setiap kejahatan. Teologi proses mengarah pada keterlibatan manusia agar bersama-sama dengan Tuhan Allah mendapatkan kemenangan atas kejahatan supaya manusia bisa menyadari sepenuhnya tanggung jawabnya dalam melawan serta melenyapkan kejahatan yan ada di dunia ini. Namun hal ini menyebabkan sebuah akhir yang abu-abu. Sedangkan dalam alkitab sendiri menjanjikan jika pada akhirnya Tuhan Allah yang akan menang atas semua kejahatan. Anggapan dari teologi proses bahwa kemenangan maupun kekalahan dalam sebuah kejahatan seutuhnya berada dalam tangan manusia ciptaan-Nya itu sendiri. ${ }^{14}$

\section{KESIMPULAN}

Teologi proses merupakan hasil dari pola pikir filsafat proses yang kemudian berkembang kedalam dunia teologi. Teologi ini memandang Allah sebagai Allah yang mengalami proses, dan mengalami perubahan secara terus menerus di bagian kutub fisik, serta tidak berpribadi dan tidak memiliki kedaulatan absolut. Dalam memahami alur pemikiran teologi proses tentu harus ada pendampingan dan penjelasan yang tepat tentang bagian mana yang bertentangan dengan Alkitab sehingga seseorang dapat mengerti jika teologi ini jauh dari kebenaran Firman Tuhan, dan berasal dari pemikiran manusia yang berusaha menjelaskan mengenai Allah dengan sisi yang logis. Berkaitan dengan hal itu maka perlu adanya tanggapan yang menunjukan perbandingan dari pola pikir teologi proses mengenai Allah yang mengarahkan seseorang dalam memahami konsep Allah yang benar sesuai dengan pernyataan Allah melalui Alkitab.

\section{KEPUSTAKAAN} 2012.

Conn, Harvie M. Teologi Kontemporer. Malang: Literatur SAAT,

Daniel, Moody Goni. "Teologi Proses." Jurnal Teologi

Biblika dan Praktika 53, no. 4 (2018).

Hermawan. "Respons Terhadap Konsepsi Allah." Jurnal

Teologi Kristen 1, no. 1 (2019).

Layantara, Jessica Novia. "Kritik Terhadap Teologi Proses

Dan Pembelaan Terhadap Pandangan 'Greater Good' Dalam Menanggapi Masalah Kejahatan." Veritas : Jurnal Teologi dan

${ }^{14}$ Layantara, "Kritik Terhadap Teologi Proses Dan Pembelaan Terhadap Pandangan 'Greater Good' Dalam Menanggapi Masalah Kejahatan." hal. 159. 
Pelayanan 16, no. 2 (2017)

Soesilo, Anodya Ariawan. "Teologi Proses Mengenai Allah Dan Problem Kejahatan: Suatu Tinjauan Atas Kasus Al-Nakba." Gema Teologika 2, no. 2 (2017)

Sugiono. Memahami Penelitian Kualitatif. Bandung: CV Alfabeta, 2016.

Suhermanto, Ja'far. "Aku Dalam Tuhan: Implikasi Teologi Proses Pada Era Kontemporer." Ulumuna 16, no. 2 (2012) 